International Journal of Life Sciences
Available online at http://sciencescholar.us/journal/index.php/ijls
Vol. 2 No. 2, August 2018, pages: $42 \sim 50$
e-ISSN: 2550-6986, p-ISSN: 2550-6994
https://doi.org/10.29332/ijls.v2n2.156

\title{
Bioactive Substance Use of Leaf Extract of Piper Caninum Blume Pressing for Blas Disease and Increase Production in Rice
}

\author{
(1) CrossMark \\ Ni Luh Suriani a \\ Article history: Received 10 March 2018, Accepted in revised form 20 June 2018, Approved 15 July 2018,
} Available online 7 August 2018

\section{Correspondence Author a}

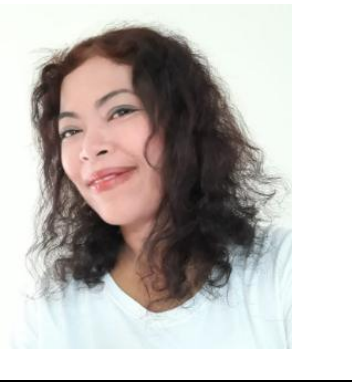

\section{Keywords}

Bioactive substances;

Blast disease;

Leaf extract;

Piper caninum;

Rice;

\begin{abstract}
The purpose of this study was to determine the effect of bioactive substances in the leaf extract of Piper caninum against rice blast disease caused by the fungus Pyricularia oryzae. This study was conducted in a greenhouse, using a completely randomized design. The results showed that the leaf extract of P. caninum formula can significantly suppress the intensity of blast disease in rice plants. The inhibition $(90.51 \%)$ contained at a concentration of $2.5 \%$. P. caninum leaf extract also significantly affect the growth and yield components. The concentration of $2.5 \%$ provides the highest grain yield (11.43 t/ha), while the extract $3.5 \%$ the intensity of the disease has increased and yield components decreased because the rice plants begin to experience toxic due to the concentration exceeding the limit too high extract optimal.
\end{abstract}

e-ISSN : 2550-6986, p-ISSN : 2550-6994@ Copyright 2018. The Author. SS Journals Published by Universidad Técnica de Manabí. This is an open-access article under the CC BY-SA 4.0 license (https://creativecommons.org/licenses/by-sa/4.0/) All rights reserved.

\section{Contents}

Abstract

1. Introduction

2. Research Method

3. Results and Analysis

3.1 Effect of leaf extract formula pipper caninum towards blas disease .......................................................... $\quad 44$

3.2 Influence of formula extract on the growth and yield components .............................................................. 45

4. Conclusion

a Department of Biology, Faculty of Mathematic and Natural Sciences, Udayana University, Indonesia 
Conflict of interest statement and funding sources.............................................................................................

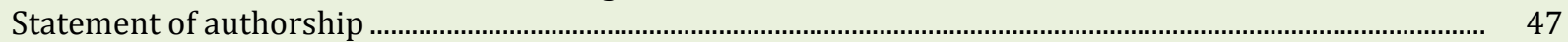

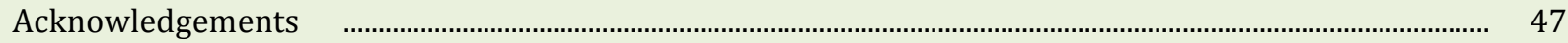

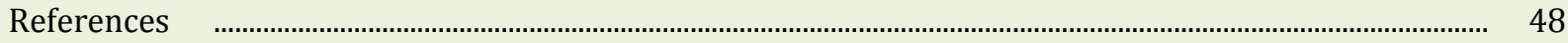

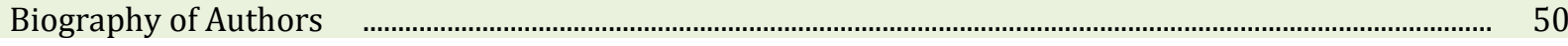

\section{Introduction}

The state of Indonesia is an agricultural country, where the majority of the Indonesian population work as farmers particularly in rice and most of the staple foods such as rice. But of late rice production continues to decrease for their pests such as blast disease caused by the fungus Pyricularia oryzae. Blast disease poses two typical symptoms, i.e., leaf blast, and panicle blast. Blas leaves are blackish brown spots, rhombic with white patches center. Blas panicle patchy dark brown at the base of the neck (Tebeest et al., 2007). Comprehensive attack blast disease in Indonesia in 2012 covering an area of 55643 ha to 146 ha Fuso category. This comprehensive higher than in 2011 covering an area of 27403 ha to 198 ha Fuso category (Kusumaninghati, 2015), Dewi \& Mustika (2018). This disease is a disease of the biggest rice, causing a decrease in yield and 50\% in endemic areas (Utami, 2006). This is caused by the overproduction of rice always use synthetic fertilizers and pesticides. Where the impact on the environment is huge because it is very difficult synthetic pesticides are broken down by microbes and cause the disease to become resistant plants undergo mutagenic. To reduce the impact of the alternative measures that can be done to increase agricultural production, especially rice but do not harm the environment is to develop environment-friendly pesticide plant (Rahmawati and Corlina, 2009).

At lately been developed plant extract that is used as a pesticide plant (Cape, 2013), Ogu \& Orjiakor (2017). Extracts of betel leaf (Piper betle) are reported to contain saponins, flavonoids and polyphenols, while the rhizome extract of galangal (Alpinia galanga) containing methoksisinamal, benzyl benzoate and antthorhiza (Tandiabang, 2007), has inhibitory effects in vitro against the fungi $P$. oryzae causes blast disease in rice , Research Suriani et al (2015) showed that the piper caninum leaf extract can inhibit the P. oryzae fungi in vitro by inhibition of $44 \mathrm{~mm}$ on PDA, but for research in the greenhouse has not been done. The study was conducted to determine the effect of the extract formula to the intensity of blast disease, and to determine the link between the concentration of the extract with intensity blast disease.

\section{Research Method}

P. oryzae Cav. causes rice blast disease isolates of $P$. oryzae of the collections available in the Laboratory of Biopesticides, Faculty of Agriculture, Udayana University. This fungus has been tested and proven pathogenicity in rice before it is used in the research.

\section{Extraction method}

P. caninum Blume was collected from plants grown in the village Senganan Penebel District, Tabanan Bali. The leaves are taken are mature leaves that leaf number 3 from top to bottom (Harborne, 1987). Collected leaves are washed with clean water to remove contaminants, then cut a little small and the wind dried for 3 days in the shade. The material then macerated in methanol at a ratio of 1:10 (weight/volume) for 48 hours in a dark place at room temperature. The filtrate obtained by filtering using 4 layers of gauze followed by filtration using Whatman filter paper No. 1. Then evaporated using a rotary evaporator (Iwaki, Tokyo) at $40^{\circ} \mathrm{C}$ to separate the solvent (methanol) and extract. The c

the crude extract obtained is ready for further testing.

\section{Greenhouse experiments}

Greenhouse experiments conducted in the village of Senganan, Penebel District, Tabanan, Bali Province by using a randomized block design (RAK), which consists of five treatment are: F0 = Control (without extract), F1 $=$ Formula extract concentration of $0.5 \%, \mathrm{~F} 2=$ Formula extract concentration of $1.5 \%, \mathrm{~F} 3=$ Formula extract

Suriani, N. L. (2018). Bioactive substance use of leaf extract of piper caninum blume pressing for blas disease and increase production in rice. International Journal of Life Sciences, 2(2), 42-50. https://doi.org/10.29332/ijls.v2n2.156 
concentration of $2.5 \%, \mathrm{~F} 4$ = Formula extract concentration of 3.5\%, and each treatment was repeated 5 times so that there are 25 experimental units. Each experimental unit consisted of 10 pots and each pot planted two seedlings. Implementation of the experiment includes: seeding, planting media preparation, seeding, fertilizing, plant maintenance, inoculation of pathogenic fungi ( $P$. oryzae), vegetable fungicide application and harvest.

The parameters observed intensity blast disease, the growth parameters (plant height, number of tillers, leaf chlorophyll content) and yield components (number of productive tillers, number of grain pithy per panicle, weight of grain pithy per panicle, percentage of filled grain hollow, the weight of 1000 seeds of grain and estimates of yield per hectare by weighing the rice produced, then all production totaled and converted into ton / ha. Measurement of the intensity of the blast disease carried by the following formula (Sinaga, 2006), Suryani and Arya (2017). I P $=\frac{\sum_{i=0}^{i}(\text { ni.vi) }}{N V} x 100 \%$. Where IP = intensity disease (\%), ni = Number of leaves with a score i, $\mathrm{vi}=$ Value disease score of each category, $\mathrm{N}=$ number of leaves were observed, $\mathrm{V}=$ highest score.

\section{Results and Analysis}

\subsection{Effect of leaf extract formula pipper caninum towards blas disease}

Blas disease progression during treatment applications where formula extract 2.5\% showed the highest inhibition (Figure 1.), where the spraying extract on 7 and 8 MST give the same effect. Treatment formula $P$ caninum leaf extract significantly $(\mathrm{P}<0.05)$ reduced the intensity of blast disease in rice plants in 8 MST $($ Table 1). Most low-intensity blast disease produced by treatment with the extract formula concentration of $2.5 \%$ in the amount of $7.43 \%$. The relationship between the concentration of the extract with the intensity of the blast disease by the equation $\mathrm{Y}=73.27 \mathrm{e}-0.62 \mathrm{x}$ with the value of $\mathrm{R}^{2}=0.809$ (figure 2 ). The higher the concentration of the extract, the intensity of the disease has declined to a concentration of $2.5 \%$, while at a concentration of $3.5 \%$ the intensity of the disease has increased. This is probably caused by the phytotoxic effect caused by the extract at a concentration of $3.5 \%$ so that the rice plants resistance to fungal infection of P. oryzae is relatively low. Suprapta (2014) states that the use of plant extracts are too high cause plant poisoning, because the plant extract in addition to containing the active substance, also contain other substances which are polar and nonpolar. Non-polar substances in excess will cause toxic. It is also possible presence of residues in extracts of leaves p. caninum, this statement is supported by Djazuli (2011) states that the patchouli leaves can poison the soil and the plant itself because it contains substances that are autoalelopati alelopati. According Zaidun (2006) that extracts of betel leaves and galangal rhizome is able to reduce the intensity of blast disease from $35.2 \%$ to $19.2 \%$ in field conditions.

Table 1

Inhibitory activity of formula of leaf extract of $P$. caninum to the intensity of blast disease on rice cultivar Ciherang

\begin{tabular}{cccc}
\hline No & $\begin{array}{c}\text { Concentration of } \\
\text { extract (\%) }\end{array}$ & $\begin{array}{c}\text { Intensity of blast } \\
\text { disease (\%) }\end{array}$ & $\begin{array}{c}\text { Inhibitory activities (\%) } \\
\text { compared with control }\end{array}$ \\
\hline 1 & 0 & $81.09 \mathrm{a}^{*}$ & - \\
2 & 0.5 & $56.03 \mathrm{~b}$ & 30.54 \\
3 & 1.5 & $32.13 \mathrm{c}$ & 58.64 \\
4 & 2.5 & $7.43 \mathrm{e}$ & 90.51 \\
5 & 3.5 & $12.93 \mathrm{~d}$ & 83.31 \\
\hline
\end{tabular}

* Means followed by the same letter do not show significant difference based on Duncan multiple range test at the level of $5 \%$. 


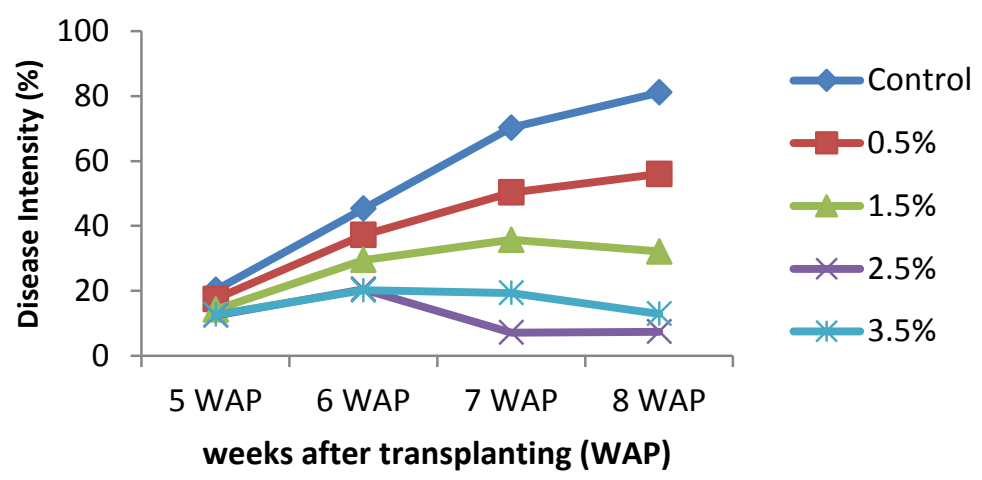

Figure 1. Development of blast disease intensity on rice cultivar Ciherang with and without treatment of the formula of leaf extract of $P$. caninum

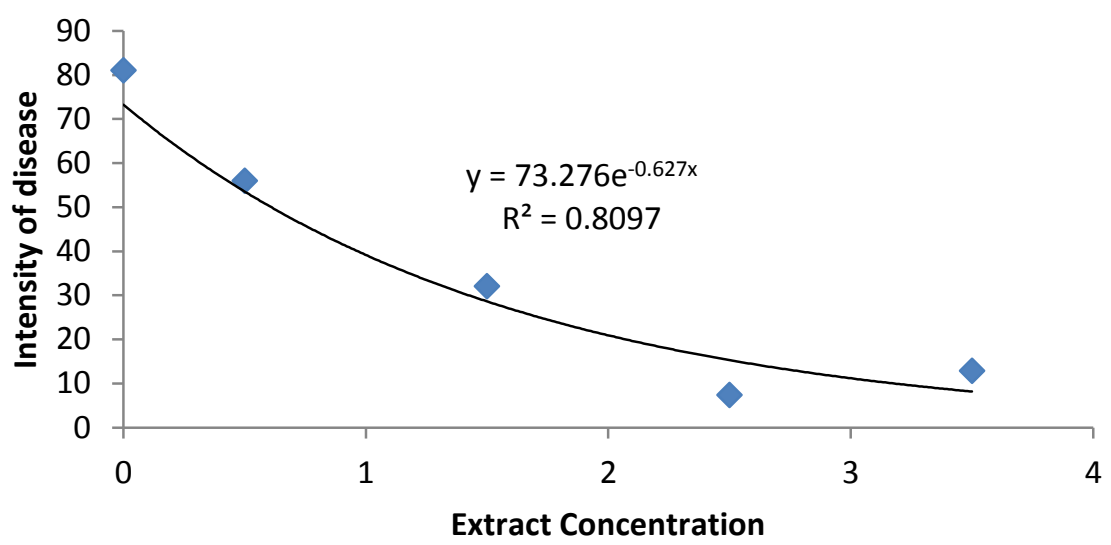

Figure 2. Chart of the relationship between forest chili leaf extract concentration and blast disease intensity

\subsection{Influence of formula extract on the growth and yield components}

Treatment formula forest chili leaf extract significantly $(\mathrm{P}<0.05)$ against the maximum number of tillers, plant height maximum and chlorophyll content of leaves (Table 2). Treatment with extract concentrations of $2.5 \%$ resulted in the number of tillers, plant height and chlorophyll levels highest among other extract concentrations tested, whereas treatment with the extract concentration of $3.5 \%$ significantly $(\mathrm{P}<0.05)$ produces the number of tillers, plant height, and chlorophyll levels lower than $2.5 \%$ concentration of the extract. This fact proves that the treatment with the extract concentration of 3.5\% inhibits the growth of rice plants. This result proves that the concentration of the extract is most appropriate to reduce the intensity of the blast disease and does not interfere with the growth of the rice plant is a $2.5 \%$ concentration of the extract.

Suriani, N. L. (2018). Bioactive substance use of leaf extract of piper caninum blume pressing for blas disease and increase production in rice. International Journal of Life Sciences, 2(2), 42-50. https://doi.org/10.29332/ijls.v2n2.156 
Table 2

Effect of forest chili leaf extract on the growth of the rice plant (plant age 60 HST)

\begin{tabular}{cccc}
\hline $\begin{array}{c}\text { Treatment } \\
(\%)\end{array}$ & Number of tillers & $\begin{array}{c}\text { Plant height } \\
(\mathrm{cm})\end{array}$ & Chlorophyll (SPAD unit) \\
\hline 0 & $29.96 \mathrm{a}^{*}$ & $79.87 \mathrm{a}^{*}$ & $32.70 \mathrm{a}^{*}$ \\
0,5 & $33.94 \mathrm{~b}$ & $85.97 \mathrm{~b}$ & $37.52 \mathrm{c}$ \\
1,5 & $34.91 \mathrm{~b}$ & $88.85 \mathrm{c}$ & $38.26 \mathrm{c}$ \\
2,5 & $36.69 \mathrm{c}$ & $92.80 \mathrm{~d}$ & $38.50 \mathrm{c}$ \\
3,5 & $33.45 \mathrm{~b}$ & $84.79 \mathrm{~b}$ & $35.72 \mathrm{~b}$ \\
\hline
\end{tabular}

* Figures followed by the same letter do not show a significant difference

based on Duncan multiple range test at the level of $5 \%$.

The treatment formula P. caninum leaf extract is also significant $(\mathrm{P}<0.05)$ to the rice crop yield components like number of productive tillers, number of grains per panicle, grain weight per clump pithy, and the percentage of empty grain (Table 3). The relationship between the concentration of the extract with the potential yield (tons $/$ ha) with the equation $y=5.015 x+5546+1.219 x 2$ with R2 $=0.896$. The higher the concentration of the extract, the grain yield (tons/ha) (figure 3) increase until the concentration of $2.5 \%$. At $3.5 \%$, the formula has decreased. This is because of the intensity of the disease at a concentration of $3.5 \%$ increase. Treatment with $2.5 \%$ extract formula gives the best results for all components of the measured results of grain weight per clump highest pithy obtained from rice plants treated woods chilli leaf extract at a concentration of $2.5 \%$ for this treatment resulted in the highest number of productive tillers, number grains per panicle highest and lowest percentage of empty grain compared with other treatments. Based on data from the pithy grain weight per hill, forest chili leaf extract treatment can improve outcomes between 39-103\% compared with controls. Potential yield per hectare obtained from this treatment is 11.43 tons, while the control plants per hectare yield potential amounted to only 5.61 tonnes (Table 3).

Table 3

The effect of forest chili leaf extract treatment on yield components of rice plants

\begin{tabular}{ccccccc}
\hline $\begin{array}{c}\text { Concentration } \\
\text { of extract (\%) }\end{array}$ & $\begin{array}{c}\text { Number of } \\
\text { productiv } \\
\text { e tillers }\end{array}$ & $\begin{array}{c}\text { Number of } \\
\text { grain/panic } \\
\text { le }\end{array}$ & $\begin{array}{c}\text { Full grain } \\
\text { weight/clump } \\
\text { (gram) }\end{array}$ & $\begin{array}{c}\text { Percentage of } \\
\text { empty } \\
\text { grain/clump } \\
\text { (\%) }\end{array}$ & $\begin{array}{c}\text { Potential } \\
\text { yield } \\
\text { (ton/ha) }\end{array}$ & $\begin{array}{c}\text { Yield increase } \\
\text { compared with control } \\
(\%)\end{array}$ \\
\hline 0 & $28.48 a^{*}$ & $79.59 a^{*}$ & $50.50 a^{*}$ & $12.54 a^{*}$ & $5.61 a^{*}$ & - \\
0.5 & $30.70 \mathrm{~b}$ & $112.99 \mathrm{~b}$ & $71.72 \mathrm{~b}$ & $7.48 \mathrm{~b}$ & $7.96 \mathrm{~b}$ & 42 \\
1.5 & $34.96 \mathrm{c}$ & $157.82 \mathrm{c}$ & $84.86 \mathrm{c}$ & $4.5 \mathrm{c}$ & $9.42 \mathrm{c}$ & 68 \\
2.5 & $38.18 \mathrm{~d}$ & $167.9 \mathrm{~d}$ & $102.87 \mathrm{~d}$ & $2.43 \mathrm{~d}$ & $11.43 \mathrm{~d}$ & 103 \\
3.5 & $33.54 \mathrm{c}$ & $112.88 \mathrm{~b}$ & $70.54 \mathrm{~b}$ & $6.99 \mathrm{~b}$ & $7.84 \mathrm{~b}$ & 39 \\
\hline
\end{tabular}

* Figures followed by the same letter do not show a significant difference based on Duncan multiple range test at the level of $5 \%$. 


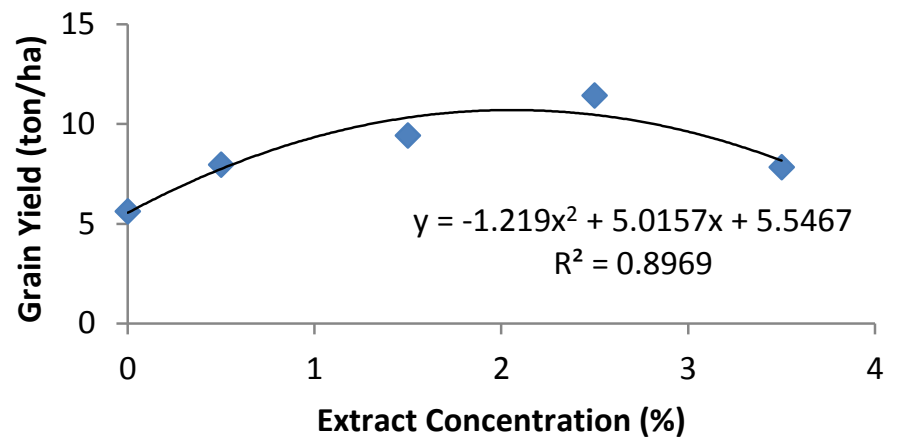

Figure 3. The relationship between the concentration of the extract and grain yield (tons/ha)

Hidayat (2012), states that the fungus P. oryzae causes blast disease can infect rice plants in the vegetative phase or generative phase. Infections that occur in the vegetative phase causes leaf blast disease and infection in the generative phase causing panicle blast disease). The occurrence of blast disease causes the vegetative phase of chlorophyll in the leaves is reduced so significantly affect the number of tillers and plant height. Likewise, a disease that occurs in the generative phase caused the blast disease malai (Groth, 2012), will affect the transport of food down to the grain so that the percentage of grain vacuum will be larger which in turn will affect the productivity of rice plants as evidenced in research this.

\section{Conclusion}

Formula forest chili leaf extracts effective in reducing the intensity of blast disease at a concentration of $2.5 \%$ in rice plants by inhibition of $90.51 \%$. The commensal higher concentration of the extracts increased grain yield, it applies under the concentration of $2.5 \%$.

\section{Conflict of interest statement and funding sources}

The author declared that she has no competing interest. The study was financed by personal funding.

Statement of authorship

The author has a responsibility for the conception and design of the study. The author has approved the final article.

\section{Acknowledgments}

The authors would like to thank the Directorate General of Education, Ministry of Education and Culture Republic of Indonesia, LPPM of Udayana University

Suriani, N. L. (2018). Bioactive substance use of leaf extract of piper caninum blume pressing for blas disease and increase production in rice. International Journal of Life Sciences, 2(2), 42-50. https://doi.org/10.29332/ijls.v2n2.156 


\section{References}

1. Akpuaka, A., Ekwenchi, M. M., Dashak, D. A., \& Dildar, A. (2013). Biological activities of characterized isolates of n-hexane extract of Azadirachta indica A. Juss (Neem) leaves. Nature and Science, 11(5), 141-147.

View in (Google Scholar)

2. Groth, D. (2012). Rice Deasease Identification. LCU Age Center. Rice Research Station . Departement of Plant Phatology and Crop Physiology.

View in (PDF)

3. Djazuli, M. U. H. A. M. A. D. (2011). Alelopati pada Beberapa Tanaman Perkebunan dan Teknik Pengendalian Serta Prospek Pemanfaatannya. Jurnal Perspektif, 10(1), 44-50.

View in (Google Scholar)

4. Galván, I. J., Mir-Rashed, N., Jessulat, M., Atanya, M., Golshani, A., Durst, T., ... \& Cruz, I. (2008). Antifungal and antioxidant activities of the phytomedicine pipsissewa, Chimaphila umbellata. Phytochemistry, 69(3), 738746.

View in (Google Scholar)

5. Harborne, J. B. (1987). Metode fitokimia: Penuntun cara modern menganalisis tumbuhan [Phytochemical methods: A guide to modern techniques of plant analysis].(K. Padmawinata, I. Soediro, \& S. Niksolihin, Trans.). Bandung, ID: ITB.(Original work published 1973).

View in (Google Scholar)

6. Khanzada, M., \& SHAH, G. S. (2012). In-vitro evaluation of fungicides, plant extracts and bio-controlagents against rice blast pathogen magnaporthe oryzae couch. Pak. J. Bot, 44(5), 1775-1778.

View in (Google Scholar)

7. Hubert, J., Mabagala, R. B., \& Mamiro, D. P. (2015). Efficacy of selected plant extracts against Pyricularia grisea, causal agent of rice blast disease.

View in (Google Scholar)

8. Ma, J., Jones, S. H., Marshall, R., Johnson, R. K., \& Hecht, S. M. (2004). A DNA-damaging oxoaporphine alkaloid from Piper caninum. Journal of natural products, 67(7), 1162-1164.

View in (Google Scholar)

9. Manjappa, K. (2013). Evaluation of Antifungal Properties of Eupatorium (Chromolaena odorata L.) Plant Exstract AgainstPyricularia oryzaeCausing Blast Disease in Rice Crop. Asean Journal of Pharmaceutical Science and Technology, 5(1), 79-81.

View in (Google Scholar)

10. Plodpai, P., Petcharat, V., Chuenchit, S., Chakthong, S., Joycharat, N., \& Voravuthikunchai, S. P. (2013). Desmos chinensis: A new candidate as natural antifungicide to control rice diseases. Industrial crops and products, 42 , 324-331.

View in (Google Scholar)

11. Murniasih, T. Metode Pengujian Antijamur Menggunakan" Conidia" Dalam Penerapannya Pada Metabolit Sekunder Dari Laut.

View in (Google Scholar)

12. Nadri, M. H., Naser, M. A., Zukifli, R. M., Muhamad, I. I., Ahmad, F., Salleh, W. M. N. H. W., \& Sirat, H. M. (2015). Antioxidant activity of Piper caninum and Cyclooxygenase-2 inhibition by methoxylated flavones. African Journal of Traditional, Complementary and Alternative Medicines, 12(2), 120-125.

View in (Google Scholar) 
13. Raman, B. V., Samuel, L. A., Saradhi, M. P., Rao, B. N., Krishna, N. V., Sudhakar, M., \& Radhakrishnan, T. M. (2012). Antibacterial, antioxidant activity and GC-MS analysis of Eupatorium odoratum. Asian Journal of Pharmaceutical and Clinical Research, 5(2), 99-106.

View in (Google Scholar)

14.Salleh, W. M. N. H. W., Ahmad, F., Yen, K. H., \& Sirat, H. M. (2011). Chemical compositions, antioxidant and antimicrobial activities of essential oils of Piper caninum Blume. International journal of molecular sciences, 12(11), 7720-7731.

View in (Google Scholar)

15.Suprapta, D. N. (2014). Pestisida Nabati: Potensi dan Prospek Pengembangan. Penerbit Pelawa Sari. Denpasar.

View in (Google Scholar)

16. Suriani, N. L. (2016). Identification of the substance bioactive leaf extract Piper Caninum potential as botanical pesticides. Int J Pure App Biosci, 4(4), 26-32.

View in (Google Scholar)

17. Suriani, N. L., Suprapta, D. N., Sudana, I. M., Temaja, I. R. M., \& Indonesia, D. B. (2015). Antifungal activity of Piper caninum against Pyricularia oryzae Cav. The cause of rice blast disease on rice. Methods, 5(8).

View in (Google Scholar)

18. Utami, D. W., Aswidinnoor, H., Moeljopawiro, S., \& Hanarida, I. (2006). Pewarisan Ketahanan Penyakit Blas (Pyricularia grisea Sacc.) pada Persilangan Padi IR64 dengan Oryza rufipogon Griff. HAYATI Journal of Biosciences, 13(3), 107-112.

View in (Google Scholar)

19. Suryani, S. A. M. P., \& Arya, I. W. (2017). Improving the Quality of Tilapia (Oreochromis niloticus) With consumption measures Leaf Extract Neem (Azadirachta indica A. Juss) as Antiparasitic. International Journal of Life Sciences (IJLS), 1(3), 28-37.

View in (Google Scholar)

20. Ogu, G. I., \& Orjiakor, P. I. (2017). Microbiological and Nutritional Qualities of Fermented Melon Seed Shells. International Journal of Life Sciences (IJLS), 1(2), 1-9.

View in (Google Scholar)

21. Dewi, N. N. A., \& Mustika, I. W. (2018). Nutrition Content and Antioxidant Activity of Black Garlic. International Journal of Health Sciences (IJHS), 2(1), 11-20.

View in (Google Scholar)

Suriani, N. L. (2018). Bioactive substance use of leaf extract of piper caninum blume pressing for blas disease and increase production in rice. International Journal of Life Sciences, 2(2), 42-50. https://doi.org/10.29332/ijls.v2n2.156 


\section{Biography of Author}

\begin{tabular}{|l|l||} 
Dr. Ni Luh Suriani, SSi., M.Si. graduated her bachelor degree in Udayana University. \\
She finished her master degree in the Institute of Pertanian Bogor. She completed \\
her doctoral degree in Udayana University. She is interested in Biology, \\
Environmental, and Agriculture. \\
Email: niluhsurianisuriani@yahoo.com
\end{tabular}

